\title{
ASESMEN TINGKAT KEMAMPUAN MAHASISWA MENGGUNAKAN SOFTWARE AUTOCAD PADA MATA KULIAH MENGGAMBAR TEKNIK
}

\author{
Gusni Vitri ${ }^{1}$, Sularno ${ }^{2}$ \\ ${ }^{1}$ Prodi Teknik Sipil, Universitas Dharma Andalas, Jl. Sawahan No. 103 A Simpang Haru Kota Padang \\ ${ }^{2}$ Prodi Sistem Informasi, Universitas Dharma Andalas, Jl. Sawahan No. 103 A Simpang Haru Kota Padang \\ email: vitri.gusni@gmail.com
}

\begin{abstract}
Civil Engineering is one of the applied sciences, covering the technology of designing, building, maintaining and repairing buildings. Students are required to understand learning material in theory and practice. One of the subjects that must be mastered by students is building drawing. The Civil Engineering Study Program of the Dharma Andalas University applies technical drawing courses with face-to-face lecture sessions, manual drawing assignments, aand practice in a computer laboratory by teaching the AutoCAD program. This research is a quantitative descriptive study with a questionnaire data collection method. Students who fill out the questionnaire are active students who have taken technical drawing courses consisting of 4 (four) batches. Students who filled the questionnaire as much as $76 \%$, and overall students completed practice and technical drawing assignments and all agreed that the ability in the science of engineering drawing must be mastered by civil engineering graduates. Students who have personal computers / laptops to study programs are $93 \%$. The level of mastery of the basic capabilities of the AutoCAD program has been understood by more than $50 \%$ of students where students understand $18.91 \%$, Understand $44.70 \%$. As for the ability to modify images, Very understand $10.25 \%$, Understand $51.75 \%$. All students are able to complete building drawing assignments and it can be concluded that students in general have mastered the AutoCAD program (the amount is above 50\%), but some learning method adjustments are needed.
\end{abstract}

Keywords: AutoCad Program, Sofware Mastery, Civil Engineeringl, Building Drawing

Teknik Sipil merupakan salah satu ilmu terapan, mencakup teknologi merancang, membangun, dan memelihara serta memperbaiki bangunan. Mahasiswa di tuntut untuk memahami materi pembelajaran secara teori dan praktek. Salah satu mata kuliah yang harus di kuasai oleh mahasiswa adalah menggambar teknik. Program Studi Teknik Sipil Universitas Dharma Andalas menerapkan mata kuliah menggambar teknik dengan sesi tatap muka kuliah, tugas menggambar secara manual, serta praktikum di laboratorium komputer dengan mengajarkan program AutoCAD. Penelitian ini merupakan penelitian deskriptif kuantitatif dengan metode pengumpulan data secara kuisioner. Mahasiswa yang mengisi kuisioner adalah mahasiswa aktif yang sudah mengambil mata kuliah menggambar teknik yang terdiri dari 4 (empat) angkatan. Mahasiswa yang mengisi kuisioner sebanyak 76\%, dan keseluruhan mahasiswa menyelesaikan praktikum dan tugas menggambar teknik serta seluruhnya setuju bahwa kemampuan dalam ilmu menggambar teknik harus dikuasai oleh lulusan teknik sipil. Mahasiswa yang mempunyai Komputer/Laptop pribadi untuk belajar program sebanyak 93\%. Tingkat penguasaan kemampuan dasar-dasar program AutoCAD sudah di pahami lebih dari 50\% mahasiswa dimana mahasiswa Sangat paham 18,91\%, Paham 44,70\%. Sedangkan untuk kemampuan modifikasi gambar, Sangat paham 10,25\%, Paham 51,75\%. Seluruh mahasiswa mampu menyelesaikan tugas menggambar teknik dan dapat disimpulkan bahwa mahasiswa pada umumnya sudah menguasai program AutoCAD (jumlahnya di atas 50\%), namun butuh beberapa penyesuaian metode pembelajaran.

Kata Kunci: Program AutoCad, Penguasaan Sofware, Teknik Sipil, Menggambar Teknik 


\section{PENDAHULUAN}

Teknik Sipil merupakan salah satu ilmu terapan, mencakup teknologi merancang, membangun, dan memelihara serta memperbaiki bangunan. Dalam pelaksanaan pembelajaran, kurikulum di rancang dengan teori dan praktek. Salah satu mata kuliah dasar yang harus di kuasai oleh mahasiswa adalah menggambar teknik. Mata kuliah ini di ajarkan dengan metode tatap muka dan praktek. Tatap muka di lakukan di kelas dengan materi teori secara umum dan detail. Sedangkan praktek, dilakukan di Laboratorium dengan menggunakan software AutoCAD. Dalam mata kuliah ini, mahasiswa di wajibkan untuk mampu membuat desain rumah sederhana secara manual maupun menggunakan program aplikasi komputer.

Automatic Computer Aided Design (AutoCAD) merupakan suatu program aplikasi komputer langsung yang dipakai untuk proses desain, rancangan, sehingga proses tersebut akan lebih mudah dan cepat dengan memanfaatkan kelebihan yang dimiliki oleh komputer seperti keakuratan, ketelitian, kecepatan serta daya ingat. Aplikasi CAD banyak sekali dipakai oleh insinyur untuk teknik rancang bangun, baik mobil, pesawat, arsitek, bangunan, sistem jaringan komputer, dan lain sebagainya.

AutoCAD merupakan salah satu program CAD yang dikeluarkan oleh perusahaan software dari Amerika, Autodesk Inc yang paling banyak dipakai di dunia ini. AutoCAD banyak dipakai karena memilki banyak kemudahan dalam hal pemakaian, lengkap fasilitasnya dan bersifat universal, fleksibel, dapat ditambah program tertentu untuk menunjang suatu aplikasi tertentu karena dalam AutoCAD terdapat bahasa pemrograman Visual LISP, VBA (Visual Basic Application). Dalam program ini, terdapat perintah dasar dan perintah modifikasi gambar lanjutan.

\section{METODE PENELITIAN}

Metode yang akan digunakan pada penelitian ini adalah metode deskriptif kuantitatif. Menurut Sudjana (1989) defenisi penelitian deskriptif adalah penelitian yang mendeskripsikan suatu gejala, fakta, peristiwa atau kejadian yang sedang atau sudah terjadi. Penelitian deskriptif terbatas pada usaha untuk mengungkap suatu masalah, keadaan atau peristiwa sebagaimana adanya sehingga bersikap sekedar untuk mengungkapkan fakta atau tanpa manipulasi. Menurut Gay (1987), ukuran minimum sampel yang dapat di terima berdasarkan pada desain penelitian yang menggunakan metode penelitian deskriptif minimal $10 \%$ populasi, untuk populasi yang relatif kecil minimal 20\%. Analisa kuantitatif adalah analisis yang menggambarkan suatu fenomena dalam bilangan atau ukuran. Dalam penelitian ini, analisa kuantitatif digunakan untuk mengetahui tingkat pemahaman mahasiswa tentang program AutoCAD sebagai pendukung mata kuliah menggambar teknik. Pengambilan data di lakukan secara langsung melalui kuisioner kepada mahasiswa.

Kesimpulan dari tingkat pemahaman mahasiswa akan menggunakan Skala Linkert. Skala Likert adalah suatu skala psikometrik yang umum digunakan dalam kuesioner, dan merupakan skala yang paling banyak digunakan dalam riset berupa survei. Nama skala ini diambil dari nama Rensis Likert, yang menerbitkan suatu laporan yang menjelaskan penggunaannya. Sewaktu menanggapi pertanyaan dalam skala Likert, responden menentukan tingkat persetujuan mereka terhadap suatu pernyataan dengan memilih salah satu dari pilihan yang tersedia. Biasanya disediakan lima pilihan skala dengan format seperti:

1. Sangat tidak setuju

2. Tidak setuju

3. Netral 
4. Setuju

5. Sangat setuju

Untuk mengambil kesimpulan tingkat pemahaman mahasiswa, dilakukan dengan pembobotan skala sebagai berikut:

1. Tidak Paham ( $0 \%-20 \%)$.

2. Kurang Paham (20\%-40\%).

3. Cukup Paham $(40 \%-60 \%)$.

4. Paham (60\%-80\%).

5. Sangat Paham $(80-100 \%)$

\section{HASIL DAN PEMBAHASAN}

Pada penelitian ini, kuesioner di isi oleh 76\% mahasiswa. Adapun hasil dari analisa jawaban mahasiswa tergambar di bawah ini :

1. Pengetahuan Dasar/Umum

\begin{tabular}{|c|c|c|}
\hline No. & Pertanyaan & Jawaban \\
\hline 1. & $\begin{array}{l}\text { Apakah Saudara/i, sudah } \\
\text { mengikuti praktikum } \\
\text { Mata Kuliah } \\
\text { Menggambar Teknik } \\
\text { dengan program } \\
\text { AutoCAD? }\end{array}$ & $\begin{array}{l}\text { Seluruhn } \\
\text { ya sudah }\end{array}$ \\
\hline 2. & $\begin{array}{l}\text { Jumlah pertemuan yang } \\
\text { Saudara/i ikuti untuk } \\
\text { sesi praktikum program } \\
\text { Autocad dalam satu } \\
\text { semester }\end{array}$ & $\begin{array}{l}10 \\
\text { pertemua } \\
n\end{array}$ \\
\hline 3 & $\begin{array}{l}\text { Seberapa penting } \\
\text { kemahiran } \\
\text { pengoperasion program } \\
\text { AutoCAD untuk } \\
\text { menunjang matakuliah } \\
\text { Menggambar Teknik? }\end{array}$ & $\begin{array}{l}\text { Sangat } \\
\text { Penting }\end{array}$ \\
\hline 4 & $\begin{array}{l}\text { Mahasiswa yang } \\
\text { mempunyai } \\
\text { komputer/Notebook } \\
\text { pribadi untuk belajar } \\
\text { Program AutoCAD }\end{array}$ & $93 \%$ \\
\hline 5 & $\begin{array}{l}\text { Pengetahuan mahasiswa } \\
\text { tentang kebutuhan } \\
\text { kapasitas memori dan } \\
\text { hardisk minimum untuk } \\
\text { menginstal program } \\
\text { autoCAD. }\end{array}$ & $\begin{array}{l}71 \% \\
\text { mahasisw } \\
\text { a } \\
\text { memaha } \\
\text { mi }\end{array}$ \\
\hline
\end{tabular}

Secara keseluruhan, mahasiswa yang mengisi kuesioner sudah mengikuti praktikum program AutoCAD dengan 10 (sepuluh) kali pertemuan. Hampir keseluruhan mahasiswa mempunyai
Komputer atau Notebook sesuai dengan spesifikasi memory dan Harddisk untuk belajar AutoCAD.

2. Pengetahuan perintah dasar penggunaan autoCAD.

\begin{tabular}{|c|c|c|}
\hline No. & Pertanyaan & Jawaban \\
\hline 1. & $\begin{array}{l}\text { Pengetahuan } \\
\text { tentang } \\
\text { sistem } \\
\text { koordinat } \\
\text { AutoCAD }\end{array}$ & $\begin{array}{l}\text { 67\% Paham, Tidak } \\
\text { Paham 33\% }\end{array}$ \\
\hline 2. & $\begin{array}{l}\text { Pengetahuan } \\
\text { dalam } \\
\text { membuat } \\
\text { garis (line) }\end{array}$ & $\begin{array}{l}\text { Sangat paham }= \\
19 \%, \text { Paham }=52 \%, \\
\text { Cukup paham } 29 \%\end{array}$ \\
\hline 3. & $\begin{array}{l}\text { Pengetahuan } \\
\text { tentang cara } \\
\text { membuat } \\
\text { garis berkait } \\
\text { (Polyline) }\end{array}$ & $\begin{array}{l}\text { Sangat Paham }= \\
26 \%, \text { Paham }=48 \%, \\
\text { Cukup Paham }=26 \%\end{array}$ \\
\hline 4. & $\begin{array}{l}\text { Pengetahuan } \\
\text { tentang } \\
\text { membuat } \\
\text { garis banyak } \\
\text { (Multiline) }\end{array}$ & $\begin{array}{l}\text { Sangat Paham }= \\
15 \%, \text { Paham }=48 \%, \\
\text { Cukup Paham }= \\
30 \%, \\
\text { Tidak Paham }=7 \%\end{array}$ \\
\hline 5. & $\begin{array}{l}\text { Pemahaman } \\
\text { membuat segi } \\
\text { banyak } \\
\text { (Polygon) }\end{array}$ & $\begin{array}{l}\text { Sangat Paham }= \\
15 \%, \text { Paham }=37 \%, \\
\text { Cukup Paham }= \\
44 \%, \text { Tidak Paham }= \\
4 \%\end{array}$ \\
\hline 6. & $\begin{array}{l}\text { Pemahaman } \\
\text { membuat } \\
\text { empat persegi } \\
\text { panjang } \\
\text { (rectangle) }\end{array}$ & $\begin{array}{l}\text { Sangat Paham }= \\
11 \%, \text { Paham } 67 \% \text {, } \\
\text { Cukup Paham } \\
22 \% .\end{array}$ \\
\hline 7. & $\begin{array}{l}\text { Pemahaman } \\
\text { membuat } \\
\text { lingkaran } \\
\text { (Circle) }\end{array}$ & $\begin{array}{l}\text { Sangat Paham = } \\
15 \%, \text { Paham = } \\
51 \%, \text { Cukup } \\
\text { Paham }=19 \%, \\
\text { Tidak Paham = } \\
15 \%\end{array}$ \\
\hline 8. & $\begin{array}{l}\text { Pemahaman } \\
\text { Seberapa } \\
\text { paham } \\
\text { saudara/i } \\
\text { Membuat } \\
\text { busur (Arc) } \\
\text { pada program } \\
\text { AutoCAD? }\end{array}$ & $\begin{array}{l}\text { Sangat Paham = } \\
11 \%, \text { Paham }= \\
33 \%, \text { Cukup } \\
\text { Paham }=41 \%, \\
\text { Tidak Paham = } \\
15 \%\end{array}$ \\
\hline 9. & $\begin{array}{l}\text { Pemahaman } \\
\text { Seberapa } \\
\text { paham }\end{array}$ & $\begin{array}{l}\text { Sangat Paham = } \\
11 \%, \text { Paham = } \\
33 \%, \text { Cukup }\end{array}$ \\
\hline
\end{tabular}




\begin{tabular}{|c|c|c|}
\hline & $\begin{array}{l}\text { saudara/i } \\
\text { Membuat } \\
\text { ellips } \\
\text { (Eclipse) } \\
\text { pada program } \\
\text { AutoCAD? }\end{array}$ & $\begin{array}{l}\text { Paham }=30 \%, \\
\text { Tidak Paham = } \\
26 \%\end{array}$ \\
\hline 10. & $\begin{array}{l}\text { Pemahaman } \\
\text { Seberapa } \\
\text { paham } \\
\text { saudara/i } \\
\text { Membuat } \\
\text { titik (Point) } \\
\text { pada program } \\
\text { AutoCAD? }\end{array}$ & $\begin{array}{l}\text { Sangat Paham = } \\
11 \%, \text { Paham = } \\
48 \%, \text { Cukup } \\
\text { Paham = 26\%, } \\
\text { Tidak Paham = } \\
15 \%\end{array}$ \\
\hline 11. & $\begin{array}{l}\text { Pemahaman } \\
\text { Seberapa } \\
\text { paham } \\
\text { saudara/i } \\
\text { Membuat } \\
\text { donut } \\
\text { (Donut) pada } \\
\text { program } \\
\text { AutoCAD? }\end{array}$ & $\begin{array}{l}\text { Sangat Paham }= \\
7 \%, \text { Paham }=30 \%, \\
\text { Cukup Paham }= \\
33 \%, \text { Tidak Paham } \\
=30 \%\end{array}$ \\
\hline
\end{tabular}

Untuk penguasaan dasar-dasar penggunaan AutoCAD, mahasiswa Sangat paham 18,91\%, Paham 44,70\%, Cukup Paham $30 \%$, Kurang paham $19,14 \%$, dan tidak paham 3,67\%. Dari data di atas, lebih dari setengah jumlah mahasiswa sudah menguasai dasar-dasar AutoCAD.

3. Kemampuan dalam memodifikasi gambar

\begin{tabular}{|l|l|l|}
\hline No. & Pertanyaan & \multicolumn{1}{c|}{ Jawaban } \\
\hline 1. & Pemahaman & Sangat Paham $=$ \\
& Seberapa & 4\%, Paham $=47 \%$, \\
& paham & Cukup Paham $=$ \\
& saudara/i & $30 \%$, Tidak Paham \\
& Menggunaka & $=19 \%$ \\
& n obyek snap & \\
& (Object Snap) & \\
& pada program & \\
& AutoCAD? & \\
\hline 2. & Pemahaman & Sangat Paham $=$ \\
& Seberapa & $7 \%$, Paham $=60 \%$, \\
& paham & Cukup Paham $=$ \\
& saudara/i & 22\%, Tidak Paham \\
& perintah & $=11 \%$ \\
& memilih & \\
& obyek pada & \\
& program & \\
& AutoCAD? & \\
\hline 3. & Pemahaman & Sangat Paham = \\
& Seberapa & $19 \%$, Paham $=$ \\
\hline
\end{tabular}

\begin{tabular}{|l|l|l|}
\hline & paham & 52\%, Cukup \\
saudara/i & Paham $=25 \%$, \\
Menggunaka & Tidak Paham =4\% \\
n teks pada & \\
program & \\
AutoCAD? & \\
\hline 4. & Pemahaman & Paham $=48 \%$ \\
& Seberapa & Sangat Paham $=$ \\
& paham & $11 \%$, Cukup \\
& saudara/i & Paham $=30 \%$, \\
Memberi & Tidak Paham $=$ \\
& dimensi & $11 \%$ \\
gambar pada & \\
program & \\
AutoCAD? & \\
\hline
\end{tabular}

Pemahaman mahasiswa tentang kemampuan dalam memodifikasi gambar sebagai berikut : Sangat paham 10,25\%, Paham 51,75\%, Cukup Paham 26,75\%, Kurang paham $11,25 \%$, dan tidak paham $0 \%$.

4. Tingkat penyelesaian tugas mahasiswa.

\begin{tabular}{|l|l|l|}
\hline No. & \multicolumn{1}{|c|}{ Pertanyaan } & Jawaban \\
\hline 1. & $\begin{array}{l}\text { Mahasiswa } \\
\text { menyelesaikan tugas } \\
\text { menggambar Teknik } \\
\text { dengan menggunakan } \\
\text { program AutoCAD }\end{array}$ & Ya 100\% \\
\hline 2. & $\begin{array}{l}\text { Ketepatan metode } \\
\text { pembelajaran } \\
\text { penggunaan Program } \\
\text { AutoCAD }\end{array}$ & $\begin{array}{l}\text { Ya }=74 \%, \\
\text { Tidak } \\
26 \%\end{array}$ \\
\hline 3. & $\begin{array}{l}\text { Program AutoCAD } \\
\text { harus di kuasai oleh } \\
\text { sarjana Teknik sipil }\end{array}$ & $\begin{array}{l}\text { Setuju } \\
100 \%\end{array}$ \\
\hline
\end{tabular}

Dari data di atas, tergambar bahwa keseluruhan mahasiswa mengetahui tentang urgensi program autoCAD dan seluruh mahasiswa menyelesaikan tugas menggambar teknik.

\section{SIMPULAN}

Dari data di atas, terlihat bahwa seluruh mahasiswa yang mengisi kuesioner penelitian sudah mengikuti praktikum AutoCAD dengan 10 (sepuluh) kali pertemuan dan mahasiswa sudah mengetahui spesifikasi komputer yang di gunakan untuk menginstall program ini. 
Hampir semua mahasiswa sudah mempunyai perangkat sendiri untuk belajar program.

Tingkat penguasaan kemampuan dasardasar program AutoCAD sudah di pahami lebih dari $50 \%$ mahasiswa dimana mahasiswa Sangat paham 18,91\%, Paham $44,70 \%$. Sedangkan untuk kemampuan modifikasi gambar, Sangat paham 10,25\%, Paham 51,75\%. Selanjutnya seluruh mahasiswa mampu menyelesaikan tugas menggambar teknik. Dari keseluruhan data di atas, maka dapat disimpulkan bahwa mahasiswa pada umumnya sudah menguasai program AutoCAD (jumlahnya di atas 50\%), namun butuh beberapa penyesuaian metode pembelajaran seperti penambahan jumlah pertemuan, mengadakan pelatihan tambahan secara berkala serta peningkatan bimbingan selama proses praktikum.

\section{DAFTAR PUSTAKA}

Cho, Dickson. 2019. Pengertian Skala Likert (Likert Scale) dan Menggunakannya. (http://www.teknikelektronika.com /pengertian-skala-likert-likertscale-menggunakan-skala-likert/)

Dwi Atmajayani, Risma.2018. Implementasi Penggunaan Aplikasi AutoCAD dalam Meningkatkan Kompetensi Dasar Menggambar teknik bagi Masyarakat. Jurnal Riset dan Konseptual Universitas Nahdlatul Ulama Blitar Vol. 3 No. 2 tahun 2018.

I Made Soma, I Made Candiasa, I Made Tegeh. 2015. Pengembangan Bahan Ajar Menggambar Dengan Perangkat Lunak Berbantuan Program Aplikasi Autocad. Jurnal Teknologi Pembelajaran Indonesia, Vol 5, No 1 tahun 2015.

Sasra M, Suparno. 2011. Aplikasi AutoCAD untuk Gambar Rancang
Bangun 2D. Jakarta, Elek Media Komputindo

Sudjana N dan Ibrahim R. 1989. Penelitian dan Penilaian Pendidikan. Sinar Baru Algesindo, Bandung.

S. Nasution, Metode Research: Penelitian Ilmiah, Jakarta: Bumi Aksara, 2009.

Rahmah, Ummiati. 2017. Pengembangan Model Sistem Pembelajaran Berbasis Komputer (SPBK) Pada Mata Kuliah Pengantar Ilmu Komputer Di Universitas Negeri Makassar. Jurnal Teknologi Pendidikan Vol. 19, No. 1, April 2017

Wahana Komputer. 2009. AutoCAD 2010 Untuk Desain Bangunan Minimalis. Jakarta, Elex Media Komputindo 